\title{
DISPUTE RESOLUTION IN THE SOUTH AFRICAN SOCIAL SECURITY SYSTEM: THE NEED FOR MORE APPROPRIATE APPROACHES
}

\author{
MAT Nyenti \\ LLB LLM LLD \\ Research Co-ordinator \\ Centre for International Comparative Labour and \\ Social Security Law (CICLASS) \\ Faculty of Law, University of Johannesburg
}

\begin{abstract}
SUMMARY
The right to social security in South Africa is adjudicated and enforced mainly by means of litigation. This article examines litigation as a mechanism for the resolution of social security disputes in South Africa and its impact on both the right to have access to court and to social security. It argues that court-based adjudication may not be the most appropriate means of adjudicating social security claims. This is particularly as South Africa is a country where social security beneficiaries have limited knowledge of the laws and procedures, coupled with a lack of publiclyprovided legal assistance/representation for social security cases. Dispute resolution mainly through the courts may contribute to the limitation of their right to seek redress and by implication, their right to have access to social security. Finally, the article proposes the investigation of more appropriate dispute-resolution processes. This is due to the failure of court-based adjudication to ensure access to justice (and to social security); constitutional requirements arising from the protection of the rights of access to justice and to social security; the Constitution's focus on protecting persons who are particularly vulnerable and desperate; the availability of other (more appropriate) dispute-resolution mechanisms; and the relatively successful implementation of these mechanisms in the resolution of social security disputes in comparative jurisdictions.
\end{abstract}

\section{DISPUTE RESOLUTION IN THE SOUTH AFRICAN} SOCIAL SECURITY SYSTEM

There are various mechanisms or processes for the resolution of disputes, and parties to a dispute should choose the most appropriate mechanism. A dispute-resolution mechanism will be appropriate where its procedure, goals and values are suitable to the requirements of the parties' situation. ${ }^{1}$ In addition, whether a mechanism is appropriate in each case will depend on

Bosch, Molahleli and Everett The Conciliation and Arbitration Handbook: A Comprehensive Guide to Labour Dispute Resolution Proceedings (2004) 7. 
the nature of the dispute, the amount of money involved, the remedies sought, the willingness of the parties to resolve the dispute and the nature of the relationship between the parties. ${ }^{2}$ At present, where social security statutes provide internal dispute-resolution mechanisms, disputes relating to entitlement and access are, in the final analysis, after exhaustion of internal social security scheme-related dispute-resolution mechanisms, resolved mainly by resort to litigation in South Africa. ${ }^{3}$

However, some of the social security statutes do not stipulate internal mechanisms for the resolution of certain disputes. In such instances, the only option for an aggrieved person is to bring an action in a court with jurisdiction (the High Court). As an example, the Compensation Commissioner for Occupational Diseases could potentially arise under the Occupational Diseases in Mines and Works Act (ODMWA), ${ }^{4}$ does not provide for the internal resolution of disputes relating to the payment of compensation by the Compensation Commissioner for Occupational Diseases (CCOD) although such disputes could arise, as well as disputes relating to the certification of diseases. Therefore, a person who is dissatisfied with by a decision of the Compensation Commissioner for Occupational Diseases must bring an action in the High Court. This is also the case with the Road Accident Fund Act. The Act states an action to enforce a claim against the Road Accident Fund or an agent of the Fund should be brought in any competent court within whose area of jurisdiction the occurrence (accident) which caused the injury or death took place. ${ }^{5}$

2 Sanders and Morrison "Mediation: Better Than Arm Wrestling" http://www.roylaw.co.za/ (accessed 2010-02-24).

3 As an example, s 18 of the Social Assistance Act 13 of 2004 provides that that if an applicant disagrees with a decision made by the Agency in respect of a matter regulated by the Act, that person or a person acting on his or her behalf may, within 90 days of his or her gaining knowledge of that decision, lodge a written appeal with the Minister against that decision, setting out the reasons why the Minister should vary or set aside that decision. The Minister may upon receipt of the applicant's written appeal and the Agency's reasons for the decision, either confirm, vary or set aside that decision; or appoint an independent tribunal to consider an appeal in accordance with such conditions as the Minister may prescribe by notice in the Gazette, and that tribunal may, after consideration of the matter, confirm, vary or set aside that decision or make any other decision which is just. If the Minister has appointed an independent tribunal, all appeals must be considered by that tribunal. In addition, the Compensation for Occupational Injuries and Diseases Act (COIDA) 130 of 1993 states that a person affected by a decision of the DirectorGeneral/Compensation Commissioner (or a trade union or employer's organisation of which the person was a member at the relevant time) may lodge an objection against that decision with the Compensation Commissioner (s 91(1) of COIDA.). Such an objection is considered and decided by a Panel composed of a Presiding officer with the assistance of two assessors (also called the Competition Court) (s 91(2) read with ss 2(1)(b) and 8(a) of COIDA). In terms of $s 91(5)(a)$, any person affected by a decision of the presiding officer may appeal to any provincial or local division of the High Court having jurisdiction against a decision regarding the interpretation of COIDA or any other law; the question whether an accident or occupational disease causing the disablement or death of an employee was attributable to his or her serious and wilful misconduct; the question whether the amount of any compensation awarded is so excessive or so inadequate that the award thereof could not reasonably have been made; and/or the right to increased compensation in terms of $s$ 56

4 Occupational Diseases in Mines and Works Act (ODMWA) 78 of 1973.

5 S 15(2) of the Road Accident Fund Act 56 of 1996. 
Few social security statutes provide for dispute resolution mechanisms other than litigation in the normal court system. Exceptions can be found in the Compensation for Occupational Injuries and Diseases Act and the Pension Funds Act. The Compensation for Occupational Injuries and Diseases Act provides for alternative mechanisms for the resolution of disputes before the Competition Court. Parties to a COIDA hearing are required to hold a pre-hearing conference if directed to do so by the Presiding Officer.

In a pre-hearing conference, the parties must attempt to reach consensus on any means by which the dispute(s) can be settled; facts that are agreed between the parties; facts that are in dispute, the issues the Presiding Officer is required to decide; the precise relief claimed the sharing and exchange of relevant documents, and the preparations of a bundle of documents in chronological order with each page numbered; the exchange of witness statements; any other means by which the proceedings may be shortened; whether an interpreter is required and, if so for how long and for which languages. Unless where a dispute is settled, the parties must draw up and sign a minute, setting out the facts on which the parties agree and disagree. An objector or his/her representative must ensure that a copy of the pre-hearing conference is delivered to the Presiding Officer within seven days of the conclusion of the pre-hearing conference. ${ }^{6}$

The Pension Funds $\mathrm{Act}^{7}$ states that to achieve the main objective of the Pension Funds Adjudicator, the Adjudicator is empowered to investigate any complaint made and may make an order as any court of law may make. ${ }^{8}$ The Adjudicator may also, if it is expedient and prior to investigating a complaint, require any complainant first to approach an organisation established for the purpose of resolving disputes in the pension funds industry or part thereof. Such organisation must have been approved by the registrar (for conciliation of the dispute). ${ }^{9}$ In an attempt to facilitate the conciliation of disputes, the Pension Funds Adjudicator has laid down guidelines and procedures for the conciliation of disputes. ${ }^{10}$

6 Rule 13 of the Rules for the Conduct of Hearings before the Compensation Court in Section 91 Hearings of COIDA.

724 of 1956.

8 The main objective of the office of the pension funds adjudicator is to dispose of complaints lodged in terms of the Act in a procedurally fair, economical and expeditious manner (s $30 D(1)$ of the Pension Funds Act).

$9 \quad \mathrm{~S} 30 \mathrm{E}(1)$ of the Pension Funds Act.

10 See Pension Funds Adjudicator Guidelines and Procedures for Conciliation at the Office of the Pension Funds Adjudicator (OPFA) 22 April 2008. The guidelines set out general procedures and principles to be followed where the adjudicator is of the view that a complaint is appropriate for conciliation. Conciliation hearings will be undertaken by independent third party conciliators appointed by the adjudicator with the approval of the registrar of pension funds. Conciliation proceedings are private and confidential and no party is entitled to legal representation. If the parties to conciliation should reach a settlement of the complaint, the adjudicator will confirm the outcome in writing to all parties by issuing a conciliation determination, which will have the same force and effect as a normal determination. Conciliation matters are organised in such a manner that the whole process is cost effective to all those involved. Where it is possible to involve both parties to a dispute in a telephonic conciliation, it is done. However, the decision is that of the 
The Pension Funds Act permits a person to approach a court with a matter that could be resolved by the Office of the Pension Funds Adjudicator. ${ }^{11}$ This has an impact on the effectiveness of the disputeresolution framework under the auspices of the Office of the Pension Funds Adjudicator. However, the presence of this dispute-resolution framework (including the availability of conciliation process) provides an alternative to the court system. Moreover, aggrieved persons can still approach the High Court if they are unhappy with the determination of the Adjudicator. ${ }^{12}$

\section{IMPACT OF LITIGATION ON THE RIGHTS TO HAVE ACCESS TO SOCIAL SECURITY AND TO COURTS}

The absence of alternative avenues for dispute resolution in South African social security statutes implies that aggrieved persons can only have their right of access to social security in the final instance enforced by the ordinary courts of law. However, the current social security adjudication system faces many problems, many of which are mostly due to the use of the ordinary courts of law. Some of these problems include undue delays in the finalisation of cases, limited access to the courts for the indigent and the high cost of court proceedings. ${ }^{13}$ This leads to the contention that:

"The current South African social security system has a large backlog in terms of the pool of beneficiaries. Yet, the adjudication system is not sufficiently specialised and localised, from the perspective of access to the system. Instead, the beneficiaries cannot financially afford the system of legal representation in the normal court context. Those who could afford to pay the costs still face a punitive snail paced legal bureaucratic process. Tedious as it is, the system leaves out the bulk of marginalised social security beneficiaries when they lodge a complaint."

Therefore, the court-based system has an adverse impact on the right to access to social security. This is because the access of

conciliator. In contrast, conciliation in terms of the Labour Relations Act (66 of 1995) is an intervention by an independent third party, who assists parties to a dispute to arrive at a mutually agreed outcome. The conciliator assists the parties to reach their own agreement, and makes no binding determination. If the dispute is settled, the agreement may be made an arbitration award or an order of court.

$11 \mathrm{~S} 30 \mathrm{H}(2)$ of the Act states that the Adjudicator shall not investigate a complaint if, before the lodging of the complaint, proceedings have been instituted in any civil court in respect of a matter which would constitute the subject matter of the investigation.

12 In terms of $\mathrm{s} 30 \mathrm{P}(1)$, any party who feels aggrieved by a determination of the Adjudicator may, within six weeks after the date of the determination, apply to the division of the High Court which has jurisdiction, for relief, and shall at the same time give written notice of his or her intention so to apply to the other parties to the complaint.

13 Committee of Inquiry into a Comprehensive System of Social Security for South Africa Transforming the Present -Protecting the Future (Draft Consolidated Report) March 2002, 124.

14 Kanyane "Exploring and Developing a Culture of Good Governance" in Olivier and Kuhnle (eds) Norms and Institutional Design: Social Security in Norway and South Africa (2008) 104. 
beneficiaries/applicants to adjudication is restricted. ${ }^{15}$ Such access is necessary for the realisation of the right to social security.

The negative impact of the current court-based adjudication system has been recognised in the South African context, as it was remarked that:

"the litigation experience is adversarial, complex, results in delay, increases costs and does not necessarily meet the needs of any of the litigants; and these aspects are particularly undesirable when the dispute concerns access to timeous and appropriate health care, rehabilitation and financial support ... In South African, courts litigation appears to be sought after rather than avoided. Court proceedings are not viewed as a last resort in the resolution of disputes. Other means (such as external mediation and arbitration) are infrequently available and less frequently used."

The effect of court-based adjudication on access to justice has also been observed in other jurisdictions. In the United Kingdom, it has been stated that the system is:

"too expensive in that the costs often exceed the value of the claim; too slow in bringing cases to a conclusion and too unequal: there is a lack of equality between the powerful wealthy litigant and the under-resourced litigant. It is too uncertain: the difficulty of forecasting what litigation will cost and how long it will last induces the fear of the unknown; and it is incomprehensible to many litigants. Above all it is ... too adversarial as cases are run by the parties, not by the Courts and the Rules of Court, all too often, are ignored by the parties and not enforced by the Court."

In the case of social security litigants, the extent to which they can do that may depend on their own qualities and resources or the qualities of their legal representatives. It is believed that many of the problems associated with (social security) adjudication systems (such as complexity, costs, delays and unfairness in the system) can be attributed to the court system.

In the South African context where the court system is extremely adversarial; where social security litigants have limited knowledge of laws and court procedures, and have little or no access to publicly-provided legal aid for social security cases, this may contribute to the limitation of the right to have access to courts to seek redress and, by implication, the right to have access to social security as guaranteed in section 27 of the Constitution. As was remarked on the situation in England and Wales during the review of the civil justice system in these countries - a situation at the time which reflected the current South African social security adjudication system - "we have to look again at our traditional approach to dispute resolution and our institutions and, while retaining their strengths, modify those features where to do so, will overcome the present shortcomings. It recognizes ... that we have to look again at our court structures, at our

15 This is contrary to the provisions of $s 34$ of the Constitution concerning the right to have access to courts.

16 Department of Transport Report of the Road Accident Fund Commission (2002) 709 and 730.

17 Woolf Access to Justice: Final Report to the Lord Chancellor on the Civil Justice System in England and Wales (1996) 2. 
procedures, our professional practices and the priority we give to civil justice". ${ }^{18}$

\section{THE NEED TO CONSIDER APPROPRIATE / ALTERNATIVE DISPUTE-RESOLUTION PROCE- DURES OR MECHANISMS}

There are various reasons why appropriate/alternative dispute-resolution mechanisms should be considered for the South African social security system. Some of these include the failure of the current adjudication mechanisms to ensure access to adjudication and to social security and thus ultimately to social justice $;^{19}$ the particularly vulnerable and desperate status of the category of persons concerned; constitutional imperatives; the availability of other more appropriate dispute-resolution mechanisms; and examples in comparative jurisdictions of the successful use of alternative dispute-resolution processes to resolve social security disputes. All these factors indicate the need and desirability to introduce alternative dispute resolution mechanisms in social security adjudication. This is to ensure proper redress for social security litigants and promote their right of access to social security.

\section{Constitutional imperatives}

The Constitution guarantees, inter alia, the right to equality before the law and the right to equal protection and benefit of the law, to non-discrimination, the litigants' rights to have access to courts/justice and social security, and the obligations on the state to respect, protect, promote and fulfil the rights in

18 The Right Honourable Lord Woolf, Address (Dinner in Honour of Lord Woolf, Osgoode Hall, 6 September 1995) (unpublished).

19 S 34 of the Constitution provides "everyone" with the right to have any dispute that can be resolved by the application of law decided in a fair public hearing before a court or, where appropriate, another independent and impartial tribunal or forum. The scope and content of the right has not been defined by legislation but through academic writings and case law. See as examples S v Makwanyane 1995 (3) SA 391 (CC); Mohlomi v Minister of Defence 1997 (1) SA 124 (CC); Department of Justice and Constitutional Development "Draft Discussion Paper: HIV/AIDS, Human Rights and Access to Justice" May 2009; AfriMAP and Open Society Foundation of South Africa "South Africa: Justice Sector and the Rule of Law (A discussion paper)" 2005; Foundation for Human Rights "Civil Society priorities in the access of justice and promotion of constitutional rights programme of the Department of Justice and Constitutional Development (DOJ\&CD)" March 2009; Anderson "Access to justice and legal process: making legal institutions responsive to poor people in LDCs" (IDS Working Paper 178) Institute of Development Studies, Sussex, February 2003; and Vawda "Access to Justice: From Legal Representation to the Promotion of Equality and Social Justice - Addressing the Legal Isolation of the Poor" 2005 Obiter 234-247. There are different facets of the right, including knowledge of rights, access to courts (facility, personnel, information, process and procedure), availability of an effective procedural remedy, access to information about the justice system, responsiveness to differences among various categories of people in accessing justice, the affordability of court procedures and legal services, the openness of courts to hearing certain types of cases, the cultural and linguistic appropriateness of the dispute resolution system, prescription, access to legal aid, representation in court, excessive court fees, the initiation or instituting of proceedings and the existence of rights enforcement mechanisms outside the courts. 
the Bill of Rights to take reasonable legislative and other measures, within its available resources, to achieve the progressive realisation of the right to have access to social security. The absence of suitable alternative avenues for dispute resolution in the social security system therefore restricts applicants' or beneficiaries' access to adjudication, ${ }^{20}$ which is necessary for the realisation of the right of access to social security. This also has an impact on their rights to equality and human dignity. As the South African Law Commission remarked:

"The (new) Constitution of South Africa, with its Bill of Rights, is based on the principle that all people are equal before the law. The problem is that the equality thus achieved will be more of a facade than a reality if people are still de facto excluded because ... they do not have the economic, social or cultural ability to make use of those rights or to participate meaningfully in the administration of justice. What is therefore necessary is an attempt to add a social dimension to the Rechtstaat in terms of which even the disadvantaged and poor will be entitled to representation and information. In this setting consideration may be given to alternative remedies and processes which may make justice fair and more accessible."

\section{The rights to have access to courts and social security}

The Constitution guarantees "everyone" the right to have any dispute that can be resolved by the application of law decided in a fair public hearing before a court or, where appropriate, another independent and impartial tribunal or forum. The right has both positive and negative components. The positive component of the right places a positive duty on the state to set up legislative and institutional mechanisms whereby all persons can realise their right of access to justice. The negative component requires state and other non-state actors to desist from preventing or impairing access to the right. Therefore, the right to have access to courts entails, firstly, that aggrieved persons should have an unfettered ability not only to bring a cause of action to a court or another adjudicating forum, but also to be able to get redress. In the second instance, the purpose of the right to have access to courts is to provide protection against actions by the state and/or other entities which deny access to the courts and other forums. ${ }^{22}$

In a rights-based constitutional society like South Africa, access to courts is about the process of enabling and empowering those not enjoying economic, social and cultural rights to claim those rights. ${ }^{23}$ Access to justice is also about breaking down the barriers that prevent the poor and indigent from participating in the social and economic life of society. Access to courts includes eliminating any procedural hurdles that prevent the free exercise of the right. Procedural rules give content to substantive rights, as:

This is contrary to $\mathrm{s} 34$ of the Constitution on the right to have access to courts.

21 South African Law Commission "Alternative dispute resolution" (Issue paper 8, Project 94) 199714.

22 Currie and De Waal The Bill of Rights Handbook (2005) 708.

23 Through, amongst other means, judicial and administrative processes. See International Human Rights Internship Programme and Asian Forum for Human Rights and Development "Circle of Rights: Economic, Social \& Cultural Rights Activism: A Training Resource" 2000 IHRIP 14. See also Vawda 2005 Obiter 239-240. 
"A substantive right on paper is of no use unless it is harnessed to an effective procedural remedy which allows the litigant to actually bring the case before the court in good time and without excessive cost. Legal gateways are important determinants of what kind of justice can be achieved. Many procedural rules which are in place in LDCs (Less Developed Countries) are out-dated or inflexible, often originating in the last century and have not been updated to reflect changes in the legal system, or to take account of the new constitutional order under which they operate. Legal procedures not only determine whether the poor can get access to legal remedies, and how quickly and effective such remedies will be, they can also influence the way that a particular dispute is construed by the law, and the kinds of outcomes which are possible."

The right further requires either a court or another "appropriate" forum to decide a dispute. While the term "appropriate" implies that an adjudicating forum other than a court must be empowered and suitable to resolve a dispute (such as the case where only a magistrate in an ordinary court can adjudicate criminal matters and order committal to prison) ${ }^{25}$ an inference can be drawn that the term also requires that the selected adjudication forum should be ideally suited for the type of dispute in question. This implies that where it is appropriate to do so, legal disputes can and should be resolved by other tribunals and forums apart from ordinary courts (such as the high court). Other adjudication forums and procedures apart from the normal courts could be preferable for a particular type of dispute due to their specialisation, expertise, the need to consider local circumstances, and the need for the adoption of expeditious, informal and inexpensive procedures. ${ }^{26}$

The right of access to courts, in conjunction with other fundamental rights, reinforce the right to have access to social security. In adjudicating social security cases, it is not only the right to have access to courts that is relevant, but also the right to have access to social security. ${ }^{27}$ Therefore, in evaluating the implications of the adjudication mechanisms used to resolve a particular social security dispute, it is not only their impact on the right to have access to courts that should be considered, but ultimately their impact on the right to have access to social security. This principle derives from the Grootboom case, where the Constitutional Court held that a right in the Bill of Rights cannot be interpreted in isolation as there is a close correlation between a particular right and the other rights. The court pointed out that the rights in the Bill of Rights are interrelated, interdependent and mutually supporting. ${ }^{28}$ The rights must all be read together in the setting of the Constitution as a whole and their interconnectedness needs to taken into account in interpreting them; and, in determining whether the state has met its obligations in terms of one of them. In the court's opinion, realising a particular right would require that other elements which form the basis of other rights must be in place as well. Together these rights have a significant

24 Anderson (IDS Working Paper 178) Institute of Development Studies, Sussex, February 2003, 15.

25 See De Lange $v$ Smuts NO 1998 (3) SA 785 (CC).

26 Currie and De Waal The Bill of Rights Handbook 723.

${ }^{27}$ S 27(1).

28 Government of the Republic of South Africa v Grootboom 2000 (11) BCLR 1169 (CC); 2001 (1) SA 46 (CC) par 24. 
impact on the dignity of people and their quality of life. ${ }^{29}$ Therefore, fulfilling the right to access to justice has an impact on the extent to which the right to have access to social security and the way in which the other rights can be realised.

A restrictive social security adjudication framework also has an impact on the state's obligations in terms of sections 7(2) and 27(2): respectively to respect, protect, promote and fulfil the rights in the Bill of Rights; and to adopt reasonable legislative and other measures, within its available resources, to achieve the progressive realisation of the right of access to social security. In terms of the obligation in section $27(2)$, the state is expected to set up the administrative and regulatory framework necessary for the realisation of this right and to create opportunities for its attainment. The legislative and other measures must be reasonable both in their conception and their implementation. ${ }^{30}$ In relation to the reasonableness of the measures adopted by the state, the Constitutional Court has held that:

"to be reasonable, measures cannot leave out of account the degree and extent of the denial of the right they endeavour to realise. Those whose needs are the most urgent and whose ability to enjoy all rights therefore is most in peril must not be ignored by the measures aimed at achieving realisation of the right.... If the measures, though statistically successful, fail to respond to the needs of those most desperate, they may not pass the test".

The reasonableness of legislative and other measures are therefore evaluated against criteria such as the social, economic and historical context of the system the measure aims to address; whether the programme is balanced, flexible and open to review, and make appropriate provision for attention to the deficiencies in the system and to short-, medium- and longterm needs; whether the programme is inclusive and does not exclude a significant segment of society; whether the measures ensure that basic human needs are met and take into account the degree and extent of the denial of the right they endeavour to realise; and whether the programme and measures ensure that a larger number of people and a wider range of people benefit from them as time progresses. ${ }^{32}$ It is doubtful whether the current social security adjudication system meets the constitutional test of reasonableness, as it fails to take into account the needs, ability, limitations and fundamental right to access of this vulnerable and desperate category.

The state must also ensure the progressive realisation of the right to social security. In the Grootboom case, the court stated that although it was contemplated that the rights in the Bill of Rights could not be realised immediately, the goal of the Constitution is that the basic needs of all in society be effectively met and the requirement of progressive realisation means that the state must take steps to achieve this goal. In the view of the

\footnotetext{
Government of the Republic of South Africa v Grootboom supra par 36. Government of the Republic of South Africa v Grootboom supra par 42.

Government of the Republic of South Africa v Grootboom supra par 44.

Government of the Republic of South Africa v Grootboom supra par 42-45. See also Committee of Inquiry into a Comprehensive System of Social Security for South Africa Transforming the Present - Protecting the Future (Draft Consolidated Report) (2002) 51.
} 
court, progressive realisation entails that accessibility should be progressively facilitated: legal, administrative, operational and financial hurdles should be examined and, where possible, lowered over time; and that rights must be made more accessible not only to a larger number of people but to a wider range of people as time progresses. ${ }^{33}$

\section{Impact of the Constitution's values and its focus on vulnerable groups}

The legislative and other measures must also give effect to, and promote all related constitutional rights, and values such as human dignity, equality, freedom and social justice. ${ }^{34}$ Constitutional values are important in the interpretation and enforcement of the rights entrenched in the Bill of Rights. ${ }^{35}$ Equality is another foundational value that informs constitutional interpretation. Equality in respect of access to courts between social security and other litigants (such as labour rights litigants) is implicit in the reference to everyone in sections 9 and 34. As a result, the absence of alternative dispute resolution mechanisms for social security litigants violates their right to equality vis-à-vis other litigants and other disciplines where such mechanisms have been implemented.

The Constitution provides that everyone is equal before the law and has the right to equal protection before the law. ${ }^{36}$ It further states that equality includes the full and equal enjoyment of all the rights and freedoms. ${ }^{37}$ This indicates that equality has two dimensions: formal and substantive equality. Formal equality entails the prohibition of unjustified discrimination, in the sense that all persons must be treated in the same manner, irrespective of their circumstances. It therefore ignores economic and social disparities between individuals or groups of persons. ${ }^{38}$ Substantive equality aims to promote the attainment of equality, by focusing on outcomes. In this case, the economic and social conditions of individuals or groups of persons are taken into account. Substantive equality dictates that the equality provisions could be used to address historical imbalances by granting more favourable treatment to the historically and socially disadvantaged.

Therefore, due to the vulnerable status of the social security beneficiaries, it could, in the light of the relevant constitutional provisions and developing jurisprudence, constitutionally be expected of government to roll out some kind of comprehensive adjudication programme to deal effectively with their

3 Government of the Republic of South Africa $v$ Grootboom supra par 45

34 Minister of Health v Treatment Action Campaign (2002) 10 BCLR 1033 (CC); (2002) 5 SA 713 (CC) par 36.

35 When interpreting the right to have access to social assistance, s 39 of the Constitution enjoins every court, tribunal or forum to promote the values that underlie an open and democratic society based on human dignity, equality and freedom.

36 S 9(1) of the Constitution.

${ }^{37} \mathrm{~S} 9(2)$ of the Constitution.

38 See generally Van Niekerk, Christianson, McGregor, Smit and van Eck Law@Work (2008) 121-122. 
plight. The absence of proper policies in this regard would certainly leave the state exposed to major constitutional challenges.

The courts have consistently stated that the state has to make provision for the most vulnerable and desperate in society. ${ }^{39}$ In the case of social security litigants, their particularly vulnerable and desperate status is indisputable. This is especially true of social assistance applicants or beneficiaries, who are indigent and have to satisfy the means test (income and asset test) to qualify for benefits. The position of social security applicants or beneficiaries is further worsened by the fact that the social security dispute resolution process - litigation - only commences after an application for a benefit has been rejected or payment of the benefit has either been stopped or only partially paid. Where the social security statute provides for internal remedies as a prerequisite for court action, these would have been exhausted. Delays in the justice system further mean that before court cases are eventually decided, most litigants will be in a very precarious financial position. Anderson asserts that the poor tend to reach court in cases where they are at risk of destitution - both because their margins for error are smaller and because the most fundamental components of livelihood are at stake. ${ }^{40}$ To compound matters for most litigants they also have to pay court and attorney fees. ${ }^{41}$ The vulnerable and desperate position of (social security) litigants was explained by Didcott $J$ when he stated that South Africa is: "a land where poverty and illiteracy abound and differences of culture and
language are pronounced, where such conditions isolate the people whom
they handicap from the mainstream of the law, where most persons who have
been injured are either unaware of or poorly informed about their legal rights
and what they should do in order to enforce these, and where access to the
professional advice and assistance that they need so sorely is often difficult
for financial or geographical reasons."

This category of persons therefore requires expeditious, efficient, affordable and easily accessible dispute resolution mechanisms and procedures. This calls for the reconsideration of the current system of litigation of social security cases and the implementation of other more appropriate dispute resolution processes. There are various examples in the South African justice system where innovative solutions have either been devised or implemented to accommodate a particular category of vulnerable and desperate persons (also in terms of adjudication and enforcement of social security rights). A prime example is the development of class actions

39 Government of the Republic of South Africa v Grootboom supra par 52 and 69, where the failure to make express provision to facilitate access to temporary (housing) relief for people who have no access to land, no roof over their heads or who live in intolerable conditions was found to fall short of the obligation set by s 26(2) in the Constitution.

40 Anderson (IDS Working Paper 178) Institute of Development Studies, Sussex, February 2003, 19-20.

41 In relation to social security (specifically social assistance) litigants' ability to pay legal fees, Wallis AJ in Cele $v$ the South African Social Security Agency and 22 related cases 2009 (5) SA 105 (D) par 2, rightly wondered how people so impoverished that they qualify for social assistance grants can afford to pay fees.

42 Didcott $\mathrm{J}$ in Mohlomi v Minister of Defence supra. 
as tools of rights enforcement as provided in section 38 of the Constitution to protect the rights of litigants. ${ }^{43}$ In the case of Permanent Secretary, The Department of Welfare, Eastern Cape Provincial Government v Ngxuza, ${ }^{44}$ the vulnerability and plight of the poor dependent upon social assistance grants caused the Supreme Court of Appeal to allow a class action to be brought on behalf of a whole group of welfare beneficiaries affected negatively by the (unlawful) suspension of a grant. In that instance the court remarked that:

"[T]he situation seemed pattern-made for class proceedings. The class the applicants present is drawn from the very poorest within our society - those in need of statutory social assistance. They also have the least chance of vindicating their rights through the legal process. Their individual claims are small: the value of the social assistance they receive - a few hundred rands every month - would secure them hardly a single hour's consultation at current rates with most urban lawyers. They are scattered throughout the Eastern Cape Province, many of them in small towns and remote rural areas. What they have in common is that they are victims of official excess, bureaucratic misdirection and unlawful administrative methods.

It is the needs of such persons, who are most lacking in protective and assertive armour, that the Constitutional Court has repeatedly emphasised must animate our understanding of the Constitution's provisions. And it is against the background of their constitutional entitlements that we must interpret the class action provision in the Bill of Rights.

The circumstances of this particular case - unlawful conduct by a party against a disparate body of claimants lacking access to individualised legal services, with small claims unsuitable for if not incapable of enforcement in isolation - should have led to the conclusion, in short order, that the applicants' assertion of authority to institute class action proceedings was unassailable."

The class and nature of social security litigants who are the very poorest of our society, warrant at least the consideration of dispute resolution mechanisms that are more appropriate to their peculiar needs and circumstances.

\section{Availability of more appropriate dispute resolution mechanisms}

Other (and relatively more appropriate) dispute resolution mechanisms or procedures are available and have been implemented in other areas of the South African justice system. The South African Law Commission, in its

${ }^{43}$ S 38 on the enforcement of rights states that: "Anyone listed in this section has the right to approach a competent court, alleging that a right in the Bill of Rights has been infringed or threatened, and the court may grant appropriate relief, including a declaration of rights. The persons who may approach a court are -

(a) anyone acting in their own interest;

(b) anyone acting on behalf of another person who cannot acting their own name;

(c) anyone acting as a member of, or in the interest of, a group or class of persons;

(d) anyone acting in the public interest; and

(e) an association acting in the interest of its members."

44 Permanent Secretary, The Department of Welfare, Eastern Cape Provincial Government v Ngxuza 2001 (4) SA 1184 (SCA) par 11. 
investigation of dispute resolution procedures that are alternatives to, and more appropriate than litigation, stated that its investigation, and other attempts to implement alternative dispute resolution procedures were to provide affordable and appropriate institutions and procedures in different communities of society; and in order to promote more effective access to justice for all the people of South Africa. ${ }^{45}$ It was envisaged that disputeresolution procedures that are alternatives to litigation will satisfy the various interest groups continually looking for speedier, more effective, less cumbersome, less expensive and often less conflicting ways of resolving disputes and problems. ${ }^{46}$

The labour relations sphere presents an example of where other dispute resolution procedures have been established with good effect, through the enactment of the Labour Relations Act (LRA). ${ }^{47}$ Section 1 of the LRA states that a primary object of the Act is to promote the effective resolution of labour disputes. ${ }^{48}$ The LRA was aimed at changing the law governing labour relations and for that purpose provides simple procedures for the resolution of labour disputes, such as negotiation, conciliation, mediation and arbitration.

Negotiation is a process of verbal interaction between parties with the objective of arriving at a mutually-acceptable agreement over a dispute. In negotiation, parties engage directly, either informally or formally, with or without facilitation, in discussions aimed at resolving the issue. ${ }^{49}$

The terms "mediation" and "conciliation" are used to refer to a consensual process where an acceptable independent third party is called in to facilitate the negotiation of a settlement between the parties. They can also be a means of dispute prevention through the identification of mutual interests and the promotion of effective communication between parties. The conciliator does not have the power to make a binding decision on the outcome of the matter, but may be required to make rulings on procedural matters. Conciliation provides for the quick and fair resolution of disputes. The conciliation process is uncomplicated, inexpensive and does not allow for any legal representation. The decision to settle is in the hands of the parties involved. An advantage of conciliation is that it extends the negotiation process and allows for settlement between the parties. Other advantages of mediation include the following: Solutions can be reached by the individuals themselves rather than by a third party such as a court; disputants have control over the process; polarisation of parties is avoided; the process is time- and cost-effective; it is simple, flexible and informal;

45 See South African Law Commission "Alternative dispute resolution" (Issue Paper 8, Project 94) (1997) 11

46 See South African Law Commission "Alternative dispute resolution" (Issue Paper 8, Project 94) (1997) 15.

47 Labour Relations Act 66 of 1995.

48 S 1(d)(iv) Labour Relations Act.

49 Bosch, Molahleli and Everett The Conciliation and Arbitration Handbook 8-11. 
wider issues are probed and resolved than is the case in a formal court system; and outcomes that are satisfactory to all parties are generated. ${ }^{50}$

Arbitration is a more formal process than conciliation. Arbitration differs from conciliation in that it does not promote the continuation of negotiations between the parties to a dispute. The arbitrator listens to and investigates the demands and counter-demands of both parties and decides on a final settlement in a form an arbitration award. The award is then imposed on the parties after hearing the evidence. This is legally binding on both parties. ${ }^{51}$

To ensure simple dispute resolution procedures, LRA established the Commission for Conciliation, Mediation and Arbitration (CCMA). The Act further provides the possibility for other independent alternative dispute resolution services to be accredited. They include Bargaining Councils ${ }^{52}$ and Statutory Councils. ${ }^{53}$ In addition, a council or private agency may apply to the governing body of the CCMA for accreditation to resolve disputes through conciliation; and to arbitrate disputes that remain unresolved after conciliation, if the Act requires arbitration. ${ }^{54}$

By establishing a new dispute resolution system that places a premium on conciliation, mediation and arbitration (and less on litigation, amongst others), the LRA was seeking to satisfy the need for expeditious, efficient and affordable procedures and easily accessible, specialist but informal institutions in specified disputes in the labour terrain. ${ }^{55}$ In addition, the dispute resolution processes before the introduction of the LRA in 1995 (mainly through adversarial litigation in the Industrial Court) resulted in only 20 percent of disputes being settled. ${ }^{56}$ However, in its 2010-2011 Annual Report, the CCMA reports that it achieved a final settlement rate of 69 percent. ${ }^{57}$ The relative success of alternative dispute resolution procedures under the auspices of the CCMA provides impetus for the adoption of the same, or at least similar, mechanisms for the resolution of some social security disputes.

In contrast to the CCMA, the Labour Court has only limited powers to resolve disputes through arbitration. In terms of the LRA, where the Labour

50 See generally, Bosch, Molahleli and Everett The Conciliation and Arbitration Handbook; and see also CCMA "Conciliation" http://www.ccma.org.za/UploadedMedia/InfoSheets_Concilia tion_1_.pdf.

51 For more, see Bosch, Molahleli and Everett The Conciliation and Arbitration Handbook; and see also CCMA "What is Arbitration" http://www.ccma.org.za/UploadedMedia/InfoSheets_ What\%20is\%20Arbitration(1).pdf.

52 Ss 27 and 35 of the LRA regulate the establishment of Bargaining Councils. In terms of $s$ 28 , one of the powers and functions of a bargaining council in relation to its registered scope is to perform the dispute resolution functions referred to in section 51 of the Act.

53 S 43 also empowers Statutory Councils to perform dispute resolution functions referred to in section 51 of the LRA.

54 S 127 of the LRA.

55 See Van Niekerk et al Law@Work 399. The LRA requires that all labour disputes must be referred to the CCMA for conciliation before referral to the next stage of the dispute resolution process.

56 Commission for Conciliation, Mediation and Arbitration (CCMA) "About Us" accessed from http://www.ccma.org.za/.

57 See CCMA Annual Report 2010-2011, 6. 
Court is of the opinion that a dispute that has been referred to it ought to have been referred to arbitration, the court may stay the proceedings and refer the dispute to arbitration; or with the consent of the parties and if it is expedient to do so, continue with the proceedings with the court sitting as an arbitrator. In this case, the court may only make any order that a commissioner or arbitrator would have been entitled to make. ${ }^{58}$

\section{Adoption/consideration of other dispute resolution procedures by comparative jurisdictions}

A further motivation for the consideration of alternatives to litigation as a social security dispute resolution procedure is provided by the shift in some comparative jurisdiction towards other dispute resolution procedures, as an alternative, or as a precursor to litigation. Examples from the United Kingdom, Australia and Germany illustrate this point. These systems provide a benchmark against which the current South African social security adjudication system is evaluated.

\section{United Kingdom}

In the United Kingdom, the resolution of social security disputes is undertaken by the Tribunals Service. ${ }^{59}$ One of the aims of the Tribunals Service is to ensure that the public at large have the opportunity to exercise their rights and to seek effective redress against Government decisions. The Tribunals, Courts and Enforcement Act empowers the Tribunals to lay down their own rules of procedure. ${ }^{60}$ The Tribunals adopt an enabling approach that allows effective access and participation. ${ }^{61}$ Therefore, the procedures of the tribunals seek to ensure the benefit of users of the system, by providing for accessibility, participation, flexibility, specialisation and efficiency. ${ }^{62}$ The guiding objectives/principles governing the interpretation and application of

$58 \quad S$ 158(2)(b) of the Labour Relations Act.

59 The Tribunals Service was established in terms of the Tribunals, Courts and Enforcement Act (TCEA)(Chapter 15) of 2007 as an Executive Agency of the Ministry of Justice to ensure a unified administration of social security and related dispute resolution. The Tribunals service consists of a two-tier tribunal system: a first-tier tribunal and an upper tribunal, both of which are split into Chambers. The First-tier Tribunal is a fact-finding tribunal that hears appeals from decisions of social security institutions. The Tribunals are composed to reflect the different requirements of particular classes of cases. The Social Entitlement Chamber of the First-tier Tribunal deals with social security issues, where cases are heard by judges and members who are trained and experienced in the complex social security laws. This ensures specialist decision-making by the tribunals.

60 S 22(2) of the TCEA. The Social Entitlement Chamber of the First-tier Tribunal is guided by the Tribunal Procedure (First-tier Tribunal)(Social Entitlement Chamber) Rules 2008 (SI No. 2685); while the Upper Tribunal is guided by the Tribunal Procedure (Upper Tribunal) Rules 2008 (SI No. 2698).

61 The tribunals are flexible in the conduct of hearings and adaptable in meeting the difficulties that parties face, especially if they are unrepresented. The features and principles of the Tribunals, if applied properly, will enable the development of an approach that meets the needs of users.

62 Jacobs "Something Old, Something New: The New Tribunal System" 2009 38(4) ILJ (UK) 417420 . 
the rules of procedure of the tribunals are the need to enable the tribunal to deal with cases fairly and justly; ${ }^{63}$ and the duty for the parties to the dispute to cooperate. ${ }^{64}$ The objectives prevent the use of the Tribunal's procedures for tactical purposes.

The Tribunals' rules of procedure provide wide case management powers. ${ }^{65}$ Case management powers include a general power to regulate their own procedure. Case management also enables the tribunal to be proactive throughout the proceedings, and not merely reactive to the application of the parties. In addition, the guiding objectives of the tribunals permit the tribunal to override the individual or even collective wishes of the parties in order to take account of the efficient operation of the system as a whole. ${ }^{66}$ In terms of the Rules, the Tribunals' case management powers are exercised through directions. ${ }^{67}$ Directions are given either on application of a party or at the tribunal's own initiative; and on application of a party or at the tribunal's own initiative if it considers it appropriate, they may be amended, suspended or set aside. The power to give directives is not only a means for the tribunal to control the progress of the proceedings, but can be used constructively to further the objectives of making the tribunals accessible and of permitting effective participation. ${ }^{68}$

This indicates that where necessary and in order to further their objectives, the Tribunals are able to adopt dispute resolution procedures other than litigation.

\section{Australia}

Australian social security applicants or beneficiaries who are aggrieved by the decisions of social security institutions (after reconsideration by the relevant institution) can approach the Social Security Appeals Tribunal $(\mathrm{SSAT}),{ }^{69}$ then the Administrative Appeals Tribunal (AAT), ${ }^{70}$ the Federal

63 Although the Act does not define justice and fairness, the rules of the tribunals provide that justice and fairness include permitting access through relative informality, flexibility and participation; allocating resources appropriately; and operating efficiently.

64 The parties to the dispute are required to cooperate with the tribunal both in general (also with each other), and in furthering the overall objective. The Tribunal and the parties to the dispute are therefore joint actors in proceedings that are conducted fairly and justly.

65 See Rule 5 of both the Tribunal Procedure (First-tier Tribunal)(Social Entitlement Chamber) Rules 2008 (SI No. 2685) and the Tribunal Procedure (Upper Tribunal) Rules 2008 (SI No. 2698).

66 Jacobs 2009 38(4) ILJ (UK) 421.

67 See Rule 6 of both the First-tier and Upper Tribunal Rules.

68 See Jacobs 2009 38(4) ILJ (UK) 421. Directions can be used to help parties understand and thereby to cooperate with the tribunal and the other parties. They can also be used to give guidance on what is required of the parties, and to help them understand the evidence that is required and the significance of failing to provide it.

69 The Social Security Appeal Tribunal is an independent statutory body within the Department for Families, Housing, Community Services and Indigenous Affairs (FaHCSIA). It was established under the Social Security (Administration) Act 1999 to conduct merits review of administrative decisions made under the social security law, the family assistance law, child support law and various other pieces of legislation. The Social Security (Administration) Act 1999, the A New Tax System (Family Assistance) (Administration) Act 1999 and the Child 
Court, the High Court, the Court of Appeals and finally to the Supreme Court.

The SSAT's statutory objective is to provide a mechanism of review that is fair, just, economical, informal and quick. Appeal applications can be lodged with the Tribunal in writing, in person or by telephone. The SSAT may hold a pre-hearing conference prior to a hearing. A pre-hearing conference usually takes place over the telephone and involves a single SSAT member and all parties to the appeal. The SSAT frequently holds a pre-hearing conference in "Change of Assessment" cases. A pre-hearing conference aims to identify the issues in dispute between the parties; identify any additional information or documents which the Tribunal considers should be provided; and where appropriate, investigate the possibility of an agreement between the parties so that a full hearing is not necessary. If parties come to an agreement during a pre-hearing conference, the terms of the agreement will need to be put in writing, signed by the parties and lodged with the SSAT. If the SSAT is satisfied that the agreement is within its powers, the SSAT may make a decision in accordance with the agreement, or part of it, without holding a further hearing.

Applicants who are not satisfied with an SSAT decision have the right to take the matter further to the Administrative Appeals Tribunal. The AAT also aims to provide a mechanism of review that is fair, just, economical, informal and quick. Section 33 of the AAT Act ${ }^{71}$ requires that proceedings of the Tribunal be conducted with as little formality and technicality, and with as much expedition, as the requirements of the Act and a proper consideration of the matters before the Tribunal permit.

The Tribunal has a case management process that aims to deal with applications in a flexible and timely manner. The case management process is designed to promote the orderly and controlled passage of matters from lodging to resolution; the achievement of case management targets; the equitable treatment of parties; the effective use and allocation of Tribunal resources; and the maintenance and enhancement of public confidence in the Tribunal.

On receipt of an application, one or more conferences, conducted by a Conference Registrar or Tribunal member, are held with the parties to discuss the issues in dispute, identify any further material that parties may wish to obtain and explore whether the matter can be settled. Conferences also provide an opportunity to discuss the future conduct of the application and, in particular, whether another form of dispute resolution may assist in resolving the matter. The other forms of dispute resolution available in the Tribunal are conciliation, mediation, case appraisal and neutral evaluation.

Support (Registration and Collection) Act 1988 set out the powers, functions and procedures of the SSAT (see SSAT Annual Report 2007-08, 21).

70 The Administrative Appeals Tribunal (AAT) is an independent and more formal body that resolves disputes between people and government agencies. The Tribunal can also review administrative decisions made by state government and non-government bodies in limited circumstances.

71 Administrative Appeals Tribunal Act of 1975. 
The Tribunal assists the parties to attempt to reach an agreed resolution, while ensuring that appropriate steps are taken to prepare for hearing those matters that are not settled. Parties are expected to play an active role in identifying legal and factual issues early in the pre-hearing process. This encourages early resolution of disputes or, where that is not possible, a clear framework within which the parties can prepare for hearing.

\section{Germany}

The German Constitution (Basic Law or Grundgesetz) guarantees everyone the right to have access to courts. Article 19(4) provides that "should any person's rights be violated by public authority, he may have recourse to the courts. If no other jurisdiction has been established, recourse shall be to the ordinary courts. In order to realise the right of access to court, the Basic Law provides for the creation of courts for the adjudication of disputes. Therefore, courts have been established for different areas of law. These include courts for the constitutional jurisdiction, the ordinary jurisdiction (civil and criminal), the labour jurisdiction, the administrative jurisdiction, the financial jurisdiction and the social jurisdiction. ${ }^{72}$ There is also a special military tribunal and a Federal Patent Court. ${ }^{73}$ Each of these jurisdictions is divided between the Federation (Bund) and the 16 federated states (Länder). There are regional and higher regional courts at the state level for each of the six major court jurisdictions and a supreme court at the federal (national) level. ${ }^{74}$

Although as a civil-law country where court procedures are considered to be quicker and less expensive (with a correspondingly less interest in other dispute resolution procedures), ${ }^{75}$ Germany has been investigating the possibility of implementing alternatives to litigation in the civil-law system. The German Code on Civil Procedure ${ }^{76}$ requires civil courts to promote the acceptance of the conciliatory or mediatory elements stipulated in the Code. Section 278(I) the Code states that the court shall, at every stage of civil proceedings, be concerned that an amicable settlement of the dispute or of individual points in dispute be reached. Section 278 (II) further requires the court always to perform a conciliation hearing (Güteverhandlung) before an oral hearing on the dispute.

72 See Articles 93 and 95 of the German Constitution.

33 Article 96 of the German Constitution. See also Bundessozialgericht Bundessozialgericht und Sozialgerichtsbarkeit - eine Information (English Summary) Kassel, September 2008, 34.

74 In the social (security) jurisdiction, the courts are organised in three levels. In the first instance are social courts (Sozialgerichte). In the second instance are state (Länder) or Higher Social Courts (Landessozialgerichte), with one for each of the sixteen German states. The Higher Social Courts hear appeals against decisions of the Social Courts. Social security adjudication in the final instance is undertaken by the Federal Social Court (Bundessozialgericht) - see Federal Ministry of Labour and Social Affairs Social Security at a Glance - Total Summary Bonn (January 2011) 162.

75 Because the South African Law Commission is of the opinion that litigation in civil-law countries is quicker and less expensive there has been correspondingly less interest in ADR - see South African Law Commission "Alternative dispute resolution" (Issue Paper 8, Project 94) (1997) 11

76 The German Code on Civil Procedure which entered into force on 1 January 2002. 
In order to promote the acceptance of the conciliation or mediation as provided in the Code on Civil Procedure a pilot project "Modellprojekt "Güterichter" (Model Project "Judge-Mediators") was launched in the Social Courts. ${ }^{77}$ During the period of the pilot project, parties involved in a social security dispute have been enabled to participate in an internal court mediation procedure following the filing of a court action or an appeal. Some court judges were trained as mediators to preside over such proceedings. Such mediation training was necessary since the judges were required to preside over matters of social law with which they are not familiar as statutory judges. ${ }^{78}$

During the model project, co-mediation was conducted which meant a second mediator participated in the proceedings. In such instances, the competent court proposed mediation to the parties concerned. This could occur at any stage in the proceedings. Mediation could also be suggested by one of the parties or their counsel. The procedure was initiated after all those involved had given their consent. During mediation, court proceedings were suspended. Successful mediation ended with concluding an agreement in writing. Subsequently, the judicial action was ended either through unanimous declarations of termination, settlement in court, withdrawal of the action, or recognition. The end of the action could occur by forwarding the concluding agreement reached in mediation to the original court. In cases where mediation failed, the action was resumed. At the initial stages of the pilot, 80 per cent of cases of mediation came to a close through a concluding agreement. $^{79}$

It has been reported that the pilot project was very successful, with a settlement rate of 70-85 per cent of the cases, although many of them were very complex. ${ }^{80}$ In addition, the parties were satisfied with the proceedings. Mediation also had positive influences on the trial practices of the courts. It is further remarked that the German Social Courts experience indicates that mediation - even in cases of pending litigation - produces speedy, appropriate and lasting solutions. ${ }^{81}$ Other positive outcomes included the relatively quick resolution of the dispute, the avoidance of wearisome proceedings and agreement with the solution reached. ${ }^{82}$

77 The project was titled "Mediation in Social Jurisdiction". See Wegen and Gack "Mediation in Pending Civil Proceedings in Germany: Practical Experiences to Strengthen Mediatory Elements in Pending Court Proceedings" in International Bar Association Mediation Newsletter (December 2006) 8 9; and Friedrich "Mediation in Social Jurisdiction" in Max Plank Institute for Foreign and International Social Law Annual Report 2006-2007 Munich, January $2008,41-42$.

lbid.

79 lbid.

80 Greger "Court Internal Mediation - Recommendations based on German Pilot Projects" (Gerichtsinterne Mediation - Regelungsempfehlungen vor dem Hintergrund der Pilotprojekte an deutschen Gerichten) Rabels Zeitschrift fuer auslaendisches und internationales Privatrecht October 2010 74(4) 781.

81 Dürschke and Rittweger "Consumer Affairs Consultations Court Mediation Association" (Vereinigung für gerichtsinterne Mediation e.V. (VGM)) 7 February 2011.

82 Wegen and Gack in International Bar Association Mediation Newsletter (December 2006) 8 9. 


\section{CONCLUSIONS AND RECOMMENDATIONS}

It is clear that the current system of social security adjudication that is focused on dispute resolution by the courts may not be the most appropriate due to its adverse effects on the applicants'/beneficiaries' rights to have access to social security and to courts. This is due to inter alia undue delays in the finalisation of cases and the high cost of court proceedings. Some South African statutes have already recognised the effects of litigation on social security beneficiaries; and have attempted to develop procedures that would facilitate the resolution of such disputes before the commencement of litigation and without delay or the incurring of substantial legal costs. These procedures are also aimed at the progressive realisation of the constitutional right to social security and the right to just administrative action.

The negative effects of court-based dispute resolution and other factors all indicate the need to at least consider the introduction of other disputeresolution procedures as an alternative, or as a precursor to litigation in South African social security adjudication. These factors include constitutional requirements (including the right to equality before the law and the right to equal protection and benefit of the law; the rights to have access to courts/justice and social security; the obligations on the state to respect, protect, promote and fulfil the rights in the Bill of Rights; and the impact of the constitution's values); the particularly vulnerable and desperate status of the category of persons concerned (and the constitution's focus on vulnerable groups); the availability of other more appropriate dispute resolution procedures.

Such a proposal is reinforced by the relative success of other dispute resolution procedures in other branches of the legal system, in particular the labour sphere. Moreover, more appropriate dispute-resolution procedures have been introduced with relative success in comparative social security jurisdictions. The reasons for the consideration of these other disputeresolution procedures in the South African social security adjudication system are thus compelling. 